\title{
Effect of spraying Lantana Fermented Extract on Growth and Yield of Green Gram (Vigna radiata L.) in Pots
}

\author{
Tanuja I. Ganagi and K.S. Jagadeesh* \\ Department of Agricultural Microbiology, University of Agricultural Sciences, \\ Dharwad 580 005, Karnataka, India \\ *Corresponding author
}

\section{A B S T R A C T}

\section{Keywords}

Lanatana camara, Lactic acid bacteria, Fermentation, Green gram

Article Info

Accepted: 10 December 2017 Available Online: 10 January 2018
Pot culture evaluation revealed that there was a significant increase in all growth parameters of green gram due to spraying with the Lanatna fermented extract (LFE) when compared with both unfermented as well as naturally fermented extracts. Between the two isolates of Lactic acid bacteria used for fermentation, DB 27 resulted in the highest values in all parameters. Its spraying twice @ $10 \mathrm{ml}$ per L was the best treatment resulting in the highest values. It increased chlorophyll content by about 40 per cent at 45 DAS. Spraying green gram seedlings with LFE significantly increased pod and grain yield. The highest grain yield was obtained by spraying twice with Lantana extract, fermented with DB 27 (@ $10 \mathrm{ml}$ per L). Thus, the present investigation has clearly brought out the potential of LFE in augmenting growth and yield attributes in green gram.

\section{Introduction}

Green gram is one of the main pulse crops in India. The important states producing this pulse are Madhya Pradesh, Maharashtra, Uttar Pradesh, Punjab, Andhra Pradesh, Rajasthan, Karnataka and Tamil Nadu. In 2013, the United Nations has declared 2016 as the international year of pulses (IYP 2016) (http://www.ipga.co.in). The IYP 2016 promises to be a milestone development in global pulse trade aiming to focus on the role of pulses in achieving food security and nutrition. The IYP program envisages for better utilization of pulse based proteins, to increase pulse production worldwide through different approaches as well as to improve trade in pulses. Any attempt to increase the pulse productivity is welcome.

Lantana camara $\mathrm{L}$. is listed as one of the important medicinal plants of the world. $L$. camara is the most widespread species of this genus, growing luxuriantly at elevations up to $2000 \mathrm{~m}$ in tropical, subtropical and temperate regions. It is an evergreen aromatic shrub and planted as an ornamental plant around houses. It has four typical colors: yellow-orange, pink violet, yellow and white flower types. It is among the top ten invasive weeds on earth 
(Sharma et al., 2005). Species of the genus Lantana have been used in several applications in folk medicine. Many studies have reported that L. camara is a rich source of many bioactive molecules, and the phytochemical studies have resulted in the isolation of many triterpenes, steroids and flavonoids (Begum et al., 2008). Often, weeds are seen as a problem rather than beneficial to the land. Many weeds and herbs are known to be mineral accumulators and are very important to the ongoing health of the soil.

Fermentation with microorganisms is known to yield high value products from raw or low grade substrates. Fermentation breaks down or converts the undesirable substrates into compatible components mediated by microbial enzymes, thereby improving the substrate properties via the production and enrichment of bioactive compounds (Parvez et al., 2006). Fermentation mediated bio-activation of the herbal medicines has resulted in improved therapeutic potencies and efficacies and decreased toxicities (Wu et al., 2013). It has been shown that during the course of Lactobacillus mediated fermentations, organic acids were released, proteins hydrolyzed and anti-oxidant ferulic acid from plant cell wall materials solubilized (Cheigh et al., 1994). It has been reported that fermentation of Anoectochilus formosanus using Lactobacillus acidophilus boosted its anti-oxidant activity by increasing the total phenol content $(\mathrm{Ng}$ et al., 2011). In another study, fermentation was used to enhance the antimicrobial potential of the crude herbal extract of Phyllanthus niruri. Fermentation was carried out using Lactobacillus acidophilus. The results indicated that the antimicrobial potential of the fermented herb was increased by about 80 per cent to 170 per cent when compared to the crude herbal extract (Venugopalan et al., 2010). Thus, fermentation of any biomass is known to release nutrients, amino acids, phenolic phytochemicals and phytohormones.
Hence, an attempt was made to ferment the biomass of Lantana weed using lactic acid bacterial (LAB) isolates and to study the effect of the fermented products on the growth and yield of green gram under pot cultures.

\section{Materials and Methods}

A pot experiment was conducted in the green house of the Department of Agricultural Microbiology, University of Agricultural Sciences, Dharwad, Karnataka, India. It was laid out in a Completely Randomized Design (CRD) with 14 treatments and 7 replications.

\section{Treatment details}

$\mathrm{T}_{1}-\mathrm{T}(\mathrm{JH})$ fermented extract, Spraying once @ $5 \mathrm{ml} / \mathrm{l}$ (30 DAS)

$\mathrm{T}_{2}-\mathrm{T}(\mathrm{JH})$ fermented extract, Spraying once @ $10 \mathrm{ml} / \mathrm{l}(30 \mathrm{DAS})$

$\mathrm{T}_{3}-\mathrm{T}(\mathrm{JH})$ fermented extract, Spraying twice @ $5 \mathrm{ml} / \mathrm{l}$ (30 and 45 DAS)

$\mathrm{T}_{4}$ - $\mathrm{T}(\mathrm{JH})$ fermented extract, Spraying twice @ $10 \mathrm{ml} / \mathrm{l}$ (30 and 45 DAS)

$\mathrm{T}_{5}$-DB 27 fermented extract, Spraying once @ $5 \mathrm{ml} / \mathrm{l}(30 \mathrm{DAS})$

$\mathrm{T}_{6}$ - DB 27 fermented extract, Spraying once @ $10 \mathrm{ml} / \mathrm{l}$ (30 DAS)

$\mathrm{T}_{7}$-DB 27 fermented extract, Spraying twice @ $5 \mathrm{ml} / \mathrm{l}$ (30 and 45 DAS)

$\mathrm{T}_{8}$-DB 27 fermented extract, Spraying twice @ $10 \mathrm{ml} / \mathrm{l}$ (30 and 45 DAS)

$\mathrm{T}_{9}$ - Water extract (natural fermented), Spraying once @ $5 \mathrm{ml} / \mathrm{l}$ (30 DAS)

$\mathrm{T}_{10}$-Water extract (natural fermented), Spraying once @ 10 ml/l (30 DAS) 
$\mathrm{T}_{11}$-Water extract (natural fermented), Spraying twice @ 5 ml/l (30 and 45 DAS)

$\mathrm{T}_{12}$ - Water extract (natural fermented), Spraying twice @ $10 \mathrm{ml} / \mathrm{l}$ (30 and 45 DAS)

$\mathrm{T}_{13}$ - Spraying Panchagavya as per POP (30 DAS)

$\mathrm{T}_{14}$ - Check (no spraying at all).

Green gram seeds of variety IPM 2-14 were soaked in the optimized concentration of the lactic acid bacterial fermented extract for 10 min. The seeds were treated with the Rhizobium biofertilizer and sown in pots. After germination, thinning was done to retain three plants in each pot.

The application of the recommended dose of FYM and N: P: S fertilizers as well as plant protection measures were taken up as per the recommended package of practices. Plant height, number of leaves per plant, chlorophyll content and dry matter production were measured at 45 days after sowing (DAS). Yield and yield components were measured after harvest of the crop.

\section{Results and Discussion}

The Lantana extract (30\%) was prepared and subjected to fermentation using two selected lactic acid bacterial (LAB) isolates separately viz., T9JH) and DB 27, for five days and the fermented extract filtered (Tanuja, 2017). This filtrate was used for spraying in the pot experiment.

The influence of spraying the Lantana Fermented Extract (LFE) at different concentrations and different number of times on growth parameters of green gram was studied in pots. In general, there was a significant increase in all the growth parameters viz., plant height, number of leaves and dry matter production due to spraying with the fermented extracts when compared with both unfermented extract as well as naturally fermented extracts (Table 1). Again, between the two isolates, DB 27 resulted in the highest values in all the parameters. And, spraying twice @ $10 \mathrm{ml} / \mathrm{l}$ was the best treatment yielding the highest values. It increased cholorophyll content by about 10 to 12 per cent at 30 DAS and up to 40 per cent at 45 DAS. LFE fermented with DB-27 isolate is enriched with phytohormones, NPK nutrients and other phytochemicals (Tanuja, 2017). All these constituents would have resulted in enhanced growth parameters and chlorophyll content as well.

Lantana fermented extracts can be considered as biostimulants. Biostimulants are extracts obtained from organic raw materials containing bioactive compounds.

The chief components of the biostimulants include mineral elements, humic acids and protein hydrolysates (Hamza and Suggars, 2001; Kauffman et al., 2007).

Biostimulants are known to act at low concentrations (Zhang and Schmidt, 1999). The effect of a biostimulant depends on environmental factors, and on the dose and time of application (Kunicki et al., 2010).

Application of biostimulants is known to increase the color of leaves by stimulating the chlorophyll content. This effect was observed in cowpea seeds pre-soaked in carrot extract (Abbas and Akladious, 2013).

Chlorophyll levels were increased and carotenoids were doubled in Rocket vegetable (Eruca sativa) when treated with Moringa oleifera extract (Abdalla, 2013). High concentration of leaf pigments resulting from biostimulant treatments in rocket has also been observed by Vernieri et al., (2006). 
Table.1 Effect of Lantana fermented extract on growth parameters and chlorophyll content of green gram in pots (45 DAS)

\begin{tabular}{|c|c|c|c|c|}
\hline Treatment & $\begin{array}{l}\text { Plant } \\
\text { height } \\
\text { (cm/ } \\
\text { plant })\end{array}$ & $\begin{array}{l}\text { No. of leaves } \\
\text { per plant }\end{array}$ & $\begin{array}{l}\text { Dry matter } \\
\text { accumulation } \\
\text { (g /plant })\end{array}$ & $\begin{array}{l}\text { Chlorophyll } \\
\text { content } \\
\text { (SPAD value } \\
\text { per plant) }\end{array}$ \\
\hline $\begin{array}{l}\text { T } 1 \text { - (T(JH) LFE spraying } \\
\text { once @ } 5 \mathrm{ml} / \mathrm{l})\end{array}$ & 22.07 & 16.37 & 0.73 & 48.5 \\
\hline $\begin{array}{l}\mathrm{T}_{2} \text { - (T(JH) LFE spraying } \\
\text { once @ } 10 \mathrm{ml} / \mathrm{l})\end{array}$ & 24.75 & 21.00 & 0.75 & 48.7 \\
\hline $\begin{array}{l}\mathrm{T}_{3}-(\mathrm{T}(\mathrm{JH}) \mathrm{LFE} \text { spraying } \\
\text { twice @ } 5 \mathrm{ml} / \mathrm{l})\end{array}$ & 26.00 & 22.75 & 0.77 & 51.2 \\
\hline $\begin{array}{l}\mathrm{T}_{4} \text { - (T(JH) LFE spraying } \\
\text { twice @ } 10 \mathrm{ml} / \mathrm{l})\end{array}$ & 27.25 & 23.75 & 0.79 & 51.7 \\
\hline $\begin{array}{l}\mathrm{T}_{5} \text { - (DB-27 LFE spraying } \\
\text { once @ } 5 \mathrm{ml} / \mathrm{l})\end{array}$ & 26.17 & 21.65 & 0.80 & 53.7 \\
\hline $\begin{array}{l}\text { T}_{6} \text { - (DB-27 LFE spraying } \\
\text { once @ } 10 \mathrm{ml} / \mathrm{l})\end{array}$ & 26.75 & 22.52 & 0.82 & 54.2 \\
\hline $\begin{array}{l}T_{7} \text { - (DB-27 LFE spraying } \\
\text { twice@ } 5 \mathrm{ml} / \mathrm{l})\end{array}$ & 27.80 & 24.57 & 0.84 & 56.1 \\
\hline $\begin{array}{l}\mathrm{T}_{8}-(\mathrm{DB}-27 \mathrm{LFE} \text { spraying } \\
\text { twice@ } 10 \mathrm{ml} / \mathrm{l})\end{array}$ & 30.02 & 25.27 & 0.86 & 58.2 \\
\hline $\begin{array}{l}\text { T9- (NFE spraying once @ } \\
5 \mathrm{ml} / \mathrm{l})\end{array}$ & 17.25 & 15.30 & 0.61 & 45.1 \\
\hline $\begin{array}{l}\text { T }_{10}-(\text { NFE spraying once } \\
\text { @ } 10 \mathrm{ml} / \mathrm{l})\end{array}$ & 20.25 & 18.37 & 0.63 & 45.4 \\
\hline $\begin{array}{l}\mathrm{T}_{11} \text { - (NFE spraying twice } \\
\text { @ } 5 \mathrm{ml} / \mathrm{l})\end{array}$ & 22.70 & 22.37 & 0.64 & 45.7 \\
\hline $\begin{array}{l}T_{12}-(\text { NFE spraying twice } \\
\text { @ } 10 \mathrm{ml} / \mathrm{l})\end{array}$ & 24.25 & 22.87 & 0.66 & 46.3 \\
\hline $\begin{array}{l}\mathrm{T}_{13} \text { - Spraying } \\
\text { panchagavya }\end{array}$ & 21.25 & 19.17 & 0.54 & 43.7 \\
\hline $\mathbf{T}_{14}-$ Check & 17.12 & 15.37 & 0.52 & 41.3 \\
\hline S. Em. \pm & 0.37 & 0.31 & 0.01 & 0.67 \\
\hline C.D. at $1 \%$ & 1.41 & 1.21 & 0.04 & 2.57 \\
\hline
\end{tabular}

Note: DAS - days after sowing

LFE - Lantana fermented extract

NFE - Natural fermented extract 
Table.2 Effect of Lantana fermented extracts on yield and Yield components of green gram at harvest

\begin{tabular}{|c|c|c|c|c|}
\hline Treatment & $\begin{array}{c}\text { No of } \\
\text { pods per } \\
\text { plant }\end{array}$ & $\begin{array}{c}\text { Pod } \\
\text { weight } \\
\text { (g/plant) }\end{array}$ & $\begin{array}{c}\text { No of } \\
\text { seeds per } \\
\text { pod }\end{array}$ & $\begin{array}{l}\text { Grain yield } \\
\text { (g/plant) }\end{array}$ \\
\hline $\begin{array}{l}\mathrm{T}_{1}-(\mathrm{T}(\mathrm{JH}) \mathrm{LFE} \text { spraying once @ } 5 \\
\mathrm{ml} / \mathrm{l})\end{array}$ & 16.67 & 9.21 & 9.67 & $5.68(25.3)$ \\
\hline $\begin{array}{l}\mathrm{T}_{2}-(\mathrm{T}(\mathrm{JH}) \text { LFE spraying once @ } 10 \\
\mathrm{ml} / \mathrm{l})\end{array}$ & 17.33 & 9.67 & 10.33 & $6.65(46.7)$ \\
\hline $\begin{array}{l}T_{3}-(T(J H) \text { LFE spraying twice @ } 5 \\
\mathrm{ml} / \mathrm{l})\end{array}$ & 18.33 & 9.93 & 10.67 & $7.03(55.1)$ \\
\hline $\begin{array}{l}\mathrm{T}_{4}-(\mathrm{T}(\mathrm{JH}) \text { LFE spraying twice @ } \\
10 \mathrm{ml} / \mathrm{l})\end{array}$ & 19.33 & 10.29 & 11.00 & $8.18(80.5)$ \\
\hline $\begin{array}{l}T_{5}-(D B-27 \text { LFE spraying once @ } 5 \\
\mathrm{ml} / \mathrm{l})\end{array}$ & 20.33 & 10.57 & 10.67 & $7.83(72.8)$ \\
\hline $\begin{array}{l}\mathrm{T}_{6} \text { - (DB-27 LFE spraying once @ } 10 \\
\mathrm{ml} / \mathrm{l})\end{array}$ & 21.33 & 10.87 & 11.33 & $9.04(99.5)$ \\
\hline $\begin{array}{l}\mathrm{T}_{7} \text { - (DB-27 LFE spraying twice @ } 5 \\
\mathrm{ml} / \mathrm{l})\end{array}$ & 22.33 & 11.01 & 11.67 & 9.47 (109.0) \\
\hline $\begin{array}{l}\mathrm{T}_{8} \text { - (DB-27 LFE spraying twice @ } \\
10 \mathrm{ml} / \mathrm{l})\end{array}$ & 23.00 & 11.17 & 12.00 & $10.58(133.5)$ \\
\hline $\mathrm{T}_{9}$ - (NFE spraying once @ $\left.5 \mathrm{ml} / \mathrm{l}\right)$ & 15.00 & 9.13 & 9.67 & $5.26(16.1)$ \\
\hline $\mathrm{T}_{10}$ - (NFE spraying once @ $\left.10 \mathrm{ml} / \mathrm{l}\right)$ & 16.00 & 9.20 & 10.00 & $6.24(37.7)$ \\
\hline $\mathrm{T}_{11}$ - (NFE spraying twice @ 5 ml/l) & 16.67 & 9.66 & 10.33 & $6.64(46.5)$ \\
\hline $\mathrm{T}_{12}$ - (NFE spraying twice@ $\left.10 \mathrm{ml} / \mathrm{l}\right)$ & 17.33 & 9.90 & 10.67 & $4.92(47.4)$ \\
\hline $\mathrm{T}_{13}$ - Spraying panchagavya & 14.33 & 8.70 & 9.33 & $4.53(8.6)$ \\
\hline $\mathbf{T}_{14}-$ Check & 13.33 & 8.61 & 9.00 & 5.68 \\
\hline S. Em. \pm & 0.267 & 0.24 & 0.285 & 0.16 \\
\hline C.D. at $1 \%$ & 1.05 & 0.97 & 1.120 & 0.63 \\
\hline
\end{tabular}

Note: DAS - days after sowing

LFE - Lantana fermented extract

NFE - Natural fermented extract

Values in parantheses indicate per cent increase values over the control 
Flavonoids are secondary metabolites of plants with polyphenolic structure. They are synthesized by the polypropanoid pathway and the startup component is phenylalanine molecule.

They constitute a wide range of substances that play an important role in protecting biological systems against the harmful effects of oxidative processes on macromolecules, such as carbohydrates, proteins, lipids and DNA (Halliwell and Gutteridge, 1989).

Recently, phenolics and flavonoids have been considered as great antioxidants and proved to be more effective than vitamin $\mathrm{C}, \mathrm{E}$ and carotenoids (Dai and Mumper, 2010). Phenols are also known to modify the endogenous levels of phytohormones (Kefeli and Dashek, 1984) which thereby influence various plant processes leading to improved yield and quality of seeds.

Foliar spraying of Brassica juncea with phenolic compounds, namely RD brown and resorcinol $\left(200 \mu \mathrm{g} \mathrm{ml}^{-1}\right.$ each) modified canopy structure of plants by increasing primary, secondary and tertiary branching (Setia et al., 1991).

The seed yield per plant was also increased greatly mainly due to significant increase in number of inflorescences and siliquae per plant, 100 seed weight and number of seeds per siliqua with these treatments.

A perusal of Table 2 indicated that spraying green gram seedlings with LFE significantly increased pod and grain yield.

The highest grain yield was obtained with the spraying of LFE, fermented with DB 27, sprayed twice @ $10 \mathrm{ml} / \mathrm{l}$. This may be attributed to the fact that the LFE is rich in NPK plant nutrients, phytohormones and other phytochemicals. The LFE, when sprayed, stimulated microbial activities and, in turn, the soil enzymatic activities (Tanuja, 2017). All these would have ultimately reflected on the increased seed germination, growth and yield attributes of green gram. Biostimulants are known to act directly on the plant physiology and metabolism or indirectly by improving the soil conditions (Nardi et al., 2009). Biostimulants in soils improve the microflora and, thus, provide positive influence on plant growth.

These products are usually applied in addition to standard fertilization treatments to improve the nutrient use efficiency and products quality (Heckman, 1994).

Thus, the findings of the preset investigation have clearly brought the potential of LFE in augmenting growth and yield attributes in green gram.

\section{References}

Abbas, S. M. and Akladious, S. A., 2013. Application of carrot root extract induced salinity tolerance in cowpea (Vigna sinensis L.) seedlings. Pakistan Journal of Botany. 45: 795-806.

Abdalla, M. M., 2013. The potential of Moringa oleifera extract as a biostimulant in enhancing the growth, biochemical and hormonal contents in rocket (Eruca vesicaria sub sp. sativa) plants. International Jouranl of Plant Physiology and Biochemistry. 5: 42-49.

Begum, S., Zehra, S. Q. and Siddiqui, B. S., 2008. Two new pentacyclic triterpenoids from Lantana camara Linn. Chemical Pharmocology. 56: 1317-1320.

Cheigh, H., Kun, Y. P. and Lee, C. Y., 1994. Biochemical, microbiological, and nutritional aspects of kimchi (Korean fermented vegetable products). Critical Reviews in Food Science and Nutrition. 34(2): 175-203.

Dai, J., and Mumper, R. J., 2010. Plant phenolics extraction, analysis and their antioxidant and anticancer properties. Journal of Molecules. 15(10): 7313-7352.

Halliwell, B. and Gutteridge, J. M. C., 1989. In free radicals in biology and medicine, Oxford University Press, Oxford (UK). 
Hamza, B. and Suggars, A., 2001. Biostimulants: myths and realities. Turfgrass Trends. 10: 6-10.

Heckman, J. R., 1994. Effect of an organic biostimulant on cabbage yield. Journal of Home Consumer Horticulture. 111-113.

Kauffman, G. L., Kneivel, D. P. and Watschke, T. L., 2007. Effects of a biostimulant on the heat tolerance associated with photosynthetic capacity, membrane thermostability and polyphenol production of perennial rye grass. Crop Science. 47: 261-267.

Kefeli, V. I. and Dashek, W. V., 1984. Nonhormonal stimulators and inhibitors of plant growth and development. Biological Reviews, 59: 273-288.

Kunicki, E., Grabowska, A., Sekara, A. and Wojciechowska, R., 2010. The effect of cultivar type, time of cultivation, and biostimulant treatment on the yield of spinach (Spinacia oleracea L.). Folia Horticulture. 22: 9-13.

Nardi, S., Carletti, P., Pizzeghello, D. and Muscolo, A., 2009. Biological activities of humic substances; in biophysicochemical processes involving natural nonliving organic matter in environmental systems. Natural Journal. 2: 305-340.

Ng, E. W., Mare, Y. and Phillip, T., 2011. Effects of yogurt starter cultures on the survival of Lactobacillus acidophilus. International Journal of Food Microbiology. 145(1): 169-75.

Parvez, S., Malik, K. A., Kang, S. and Kim, H. Y., 2006. Probiotics and their fermented food products are beneficial for health.
Journal of Applied Microbiology. 100(6): 1171-1185.

Setia, R. C., Neelam, R. S. and Malik, C. P., 1991. Effect of phenolic compounds on growth, yield and quality of Indian mustard (Brassica juncea). Proceedings of Indian National Science and academy, 57(6): 407-412.

Sharma, G. P., Raghubanshi, A. S. and Singh, J. S., 2005. Lantana invasion: An overview. Weed Biology and Management, 5: 157167.

Tanuja, I. Ganagi, 2017. Effect of lactic acid bacterial fermented Lantana camara extract on the growth and yield of Green gram (Vigna radiata L.). MSc Thesis submitted to University of Agricultural Sciences, Dharwad, India.

Venugopalan, V., Dinesh, M. S. and Geetha, K. S., 2010. Enhancement of antimicrobial potential of Phyllanthus niruri by fermentation. Journal of Herbal Medicine and Toxicology, 4(2): 167-175.

Vernieri, P., Ferrante, A., Borghesi, E. and Magnani, G., 2005. High quality flowering plants using the biostimulants. Informatory Agrarian. 16: 57-60.

Wu, T. X., Wang, N., Zhang, Y. and Xu, X. B., 2013. Advances in the study on microbial fermentation and transformation of traditional Chinese medicine. African Journal of. Microbiological Research. 7(17): 1644-1650.

Zhang, X. and Schmidt, R. E., 1999. Biostimulating turfgrasses. Ground Maint, 34: 14-32.

\section{How to cite this article:}

Tanuja I. Ganagi and Jagadeesh, K.S. 2018. Effect of Spraying Lantana Fermented Extract on Growth and Yield of Green Gram (Vigna radiata L.) in Pots. Int.J.Curr.Microbiol.App.Sci. 7(01): 1187-1193. doi: https://doi.org/10.20546/ijcmas.2018.701.144 